\title{
Serosurvey of Rickettsia spp. in cats from a Brazilian spotted fever-endemic area
}

\author{
Soroprevalência de Rickettsia spp. em gatos de uma área endêmica para a Febre Maculosa Brasileira \\ Juliana Cristina Rebonato Mendes ${ }^{1}$; Louise Bach Kmetiuk ${ }^{1}$; Camila Marinelli Martins ${ }^{2}$; Aurea Maria Oliveira Canavessi; \\ Tatiana Jimenez ${ }^{4}$; Maysa Pellizzaro5; Thiago Fernandes Martins ${ }^{5}$; Vivien Midori Morikawa ${ }^{6}$; Andrea Pires dos Santos ${ }^{7}$; \\ Marcelo Bahia Labruna ${ }^{4}$; Alexander Welker Biondo ${ }^{*}$ \\ ${ }^{1}$ Departamento de Biologia Celular e Molecular, Universidade Federal do Paraná - UFPR, Curitiba, PR, Brasil \\ ${ }^{2}$ Departamento de Enfermagem e Saúde Pública, Universidade Estadual de Ponta Grossa - UEPG, Ponta Grossa, PR, Brasil \\ ${ }^{3}$ Departamento de Ciência Animal, Universidade de São Paulo - USP, Piracicaba, SP, Brasil \\ ${ }^{4}$ Departamento de Medicina Veterinária Preventiva e Saúde Animal, Escola de Medicina Veterinária e Saúde Animal, Universidade de \\ São Paulo - USP, São Paulo, SP, Brasil \\ ${ }^{5}$ Departamento de Higiene Veterinária e Saúde Pública, Escola de Medicina Veterinária, Universidade Estadual Paulita - UNESP, \\ Botucatu, SP, Brasil \\ ${ }^{6}$ Departamento de Saúde Coletiva, Universidade Federal do Paraná - UFPR, Curitiba, PR, Brasil \\ ${ }^{7}$ Department of Comparative Pathobiology, Purdue University, West Lafayette, IN, USA
}

Received September 20, 2019

Accepted October 11, 2019

\begin{abstract}
Rickettsia spp. bacteria are responsible for tick-borne diseases worldwide, mostly maintained by rickettsial amplifiers capybaras in Brazilian endemic areas. The campus of the University of São Paulo, in southeastern Brazil, is an area endemic for Brazilian spotted fever (BSF), with high density of capybaras and Amblyomma spp., along with confirmed human cases. Besides capybaras, the university has also an in-campus high population of sheltered and free-roaming cats. Accordingly, the aim of this study was to determine the prevalence and characteristics associated with Rickettsia rickettsii, Rickettsia parkeri and Rickettsia felis exposure among cats in a BSF-endemic area. Out of 51 cats sampled, 23/35 shelter $(65.7 \%)$ and 5/16 free-roaming $(31.2 \%)$ were positive (titers $\geq 64$ ) for at least one Rickettsia species. Ticks species were present in 3/16 free-roaming cats (18.8\%), consisting of Amblyomma spp., nymphs of Amblyomma sculptum and adult Rhipicephalus sanguineus sensu lato. Despite sharing the capybaras environment, the seropositivity among the free-roaming and shelter cats was lower than owned cats in other endemic areas. Whether equally or less exposed to rickettsial infection, compared with owned cats in endemic areas, free-roaming and shelter cats may be used as environmental sentinels for human exposure to rickettsiae in such areas.
\end{abstract}

Keywords: Rickettsia rickettsii, Rickettsia parkeri, brazilian spotted fever.

\section{Resumo}

Espécies de Rickettsia têm sido responsáveis por doenças transmitidas por carrapatos no mundo, a maioria mantida por hospedeiros amplificadores, como as capivaras em áreas endêmicas no Brasil. A Universidade de São Paulo, em Piracicaba, no sudeste do Brasil, é uma área endêmica para a Febre Maculosa Brasileira (FMB), com alta densidade de capivaras e Amblyomma spp., e com casos humanos confirmados. Além de capivaras, a universidade também possui gatos em um abrigo e de vida livre. Assim, o objetivo deste estudo foi determinar a prevalência e as características associadas com exposição à Rickettsia rickettsii, Rickettsia parkeri e Rickettsia felis em gatos de área endêmica para a FMB. Dos 51 gatos amostrados, 23/35 (65,7\%) do abrigo e 5/16 (31,2\%) de vida livre foram positivos (títulos $\geq 64)$ para pelo menos uma Rickettsia spp. Carrapatos estiveram presentes em 3/16 (18,8\%) gatos de vida livre, representados por Amblyomma spp., ninfas de Amblyomma sculptum e adultos de Rhipicephalus sanguineus sensu lato. Apesar de compartilharem o ambiente com capivaras, os gatos amostrados foram igualmente ou menos expostos à infecçáo riquetsial do que os gatos com proprietário em outras áreas endêmicas, podendo ser usados como sentinelas para exposição humana à riquétsias nessas áreas.

Palavras-chave: Rickettsia rickettsii, Rickettsia parkeri, febre maculosa brasileira.

${ }^{*}$ Corresponding author: Alexander Welker Biondo. Departamento de Medicina Veterinária, Universidade Federal do Paraná - UFPR, Rua dos Funcionários, 1540, Juvevê, CEP 80035-050, Curitiba, PR, Brasil. e-mail: abiondo@ufpr.br 


\section{Introduction}

Rickettsia bacteria are responsible for human and animal diseases worldwide, such as Brazilian spotted fever (BSF) and ixodid ticks are the main vectors of rickettsiae (BENINATI et al., 2005; LABRUNA, 2009). BSF cases in endemic areas of southeastern Brazil have been previously related to two main pathogenic species, namely Rickettsia rickettsii and Rickettsia parkeri (LABRUNA et al., 2014; NIERI-BASTOS et al., 2018).

Presence of capybaras (Hydrochoerus hydrochaeris) has been reportedly correlated with endemic areas for BSF in southeastern Brazil, with capybara population 40 times higher when compared to natural environments, mostly related to extensive sugarcane crops (POLO et al., 2015). Capybaras have been recognized as Rickettsia rickettsii amplifiers and as hosts for ticks, especially Amblyomma sculptum (LABRUNA, 2009; SOUZA et al., 2009).

Despite the urban location of the campus of the University of São Paulo in the city of Piracicaba, it is composed of extensive green areas, with native vegetation and natural river courses. This type of terrain has historically been described as capybaras' natural habitat. Because of expansion of sugarcane crop areas surrounding the city, which provide an important food source for capybaras, an increase in the on-campus population of capybaras infested by ticks has been described (GHELER-COSTA et al., 2002). Hence, not surprisingly, the city of Piracicaba alone (among the 650 municipalities in this state) has accounted for $62(7.6 \%)$ out of the total of 814 human BSF cases in the state of São Paulo over the past 12 years, including fatal cases after tick bites that were acquired on campus (SÃO PAULO, 2019). In addition, high seropositive capybara population has overlapped around 250 free-roaming in-campus cats, according to campus administration.

The seroprevalence of Rickettsia spp. in cats (Felis catus) has been variable in South and North America. In South America, a report on trapped stray cats in four endemic areas in the state of São Paulo (including Piracicaba) found the highest cat seropositivity worldwide, such that $16 / 19$ (84.21\%) were seropositive to $R$. rickettsii antigen, $15 / 19$ (78.94\%) to $R$. parkeri, and $14 / 19(73.68 \%)$ to $R$. felis, with highest endpoint titers to $R$. rickettsii (HORTA et al., 2007). In North America, seropositivity of $R$. rickettsii ranged from $9 / 36(25.0 \%)$ to $22 / 52(42.3 \%)$ feral cats, $2 / 20(10.0 \%)$ to $23 / 29(79.3 \%)$ owned cats and $14 / 114$ (12.3) sheltered cats (CASE et al., 2006; KELLY et al., 2017; STEPHENSON et al., 2017). The tick $A$. sculptum has been found infesting cats in Piracicaba city, suggesting that wild-animal reservoirs and vectors may spread rickettsial pathogens among feral cats and human hosts (HORTA et al., 2007).

Although the impact of capybara populations on human BSF cases has been extensively studied, the impact of overlapping free-roaming cat populations for the tick-borne diseases remains to be established. Accordingly, the aim of this study was to assess the prevalence and characteristics associated with tick-borne diseases, selected by cat exposure of main pathogenic species in BSF-endemic areas overlapping capybaras, reportedly $R$. rickettsii and $R$. parkeri. In addition, serum samples were tested to anti-R. felis antibodies.

\section{Methods}

\section{Study area}

This study was conducted at the Escola Superior de Agricultura "Luiz de Queiroz"

Universidade de São Paulo (ESALQ-USP), in the city of Piracicaba, from July to October 2017. The municipality of Piracicaba has a total area of $1,378.069 \mathrm{~km}^{2}$; its altitude is 554 meters, its temperatures range is from $16.0{ }^{\circ} \mathrm{C}$ to $37.5^{\circ} \mathrm{C}$ and its annual rainfall is 123 centimeters. The estimated city population at the time of the survey was 400,100 inhabitants (ranked $61^{\text {st }}$ in size out of the total of 5,570 Brazilian municipalities), with a high human development index (HDI) of 0.785 (ranked 92 ${ }^{\text {nd }}$ among all Brazilian municipalities) (IBGE, 2017).

The university campus (915 hectares) is located within the urban area of Piracicaba city and is divided between forest remnants of the Atlantic Forest biome and diverse anthropic uses, including landscaped and idle areas, crops and rural facilities, pasture and restored forests (Figure 1). The campus harbors native fauna, mostly consisting of birds, capybaras and opossums, with four kilometers of on-campus river course (ESALQ, 2019).

\section{Animal sampling and testing}

It was estimated that around 250 free-roaming resident cats were present on campus at the time of the survey, according to the campus administration, living on offered cat food and hunting birds and rodents. Traps were distributed in several on-campus locations during a four-month trapping period. In addition, 35 cats and 12 dogs from a provisional on-campus animal shelter were sampled.

After trapping and/or physical restraint, blood samples from $35 / 51$ shelter cats $(68.6 \%)$ and $16 / 250$ free-roaming cats $(6.4 \%)$ were successfully collected. Because of the death of a shelter feral cat following blood sampling, caused by a preexisting hypertrophic cardiomyopathic condition that was found later at the necropsy, sampling from shelter and free-roaming feral cats was limited by campus mayor to the four-month trapping period only, which limited the number of collected samples.

All the samples were collected in tubes without anticoagulant and were kept at room temperature $\left(25^{\circ} \mathrm{C}\right)$ until visible clot retraction occurred. They were then centrifuged at 1,500 revolutions per minute for five minutes, and the serum was separated and stored at $-20{ }^{\circ} \mathrm{C}$ until the indirect immunofluorescence assay (IFA) procedure was performed (ZAVALA-VELAZQUEZ et al., 1996). The serum samples were tested by means of IFA to detect IgG antibodies against the $R$. rickettsii strain Taiaçu, and the $R$. parkeri strain At24, which are spotted fever group (SFG) rickettsiae, and additionally tested to $R$. felis strain Pedreira, a transitional group rickettsia. Individual serum samples were initially screened at 1:64 dilutions against each of the rickettsial antigens. A fluorescein isothiocyanate-labeled rabbit anti-cat and anti-dog IgG dilution of 1:1,500 (IgG, Sigma Diagnostics, St. Louis, MO, USA) as conjugate was used for the cat and dog samples. 


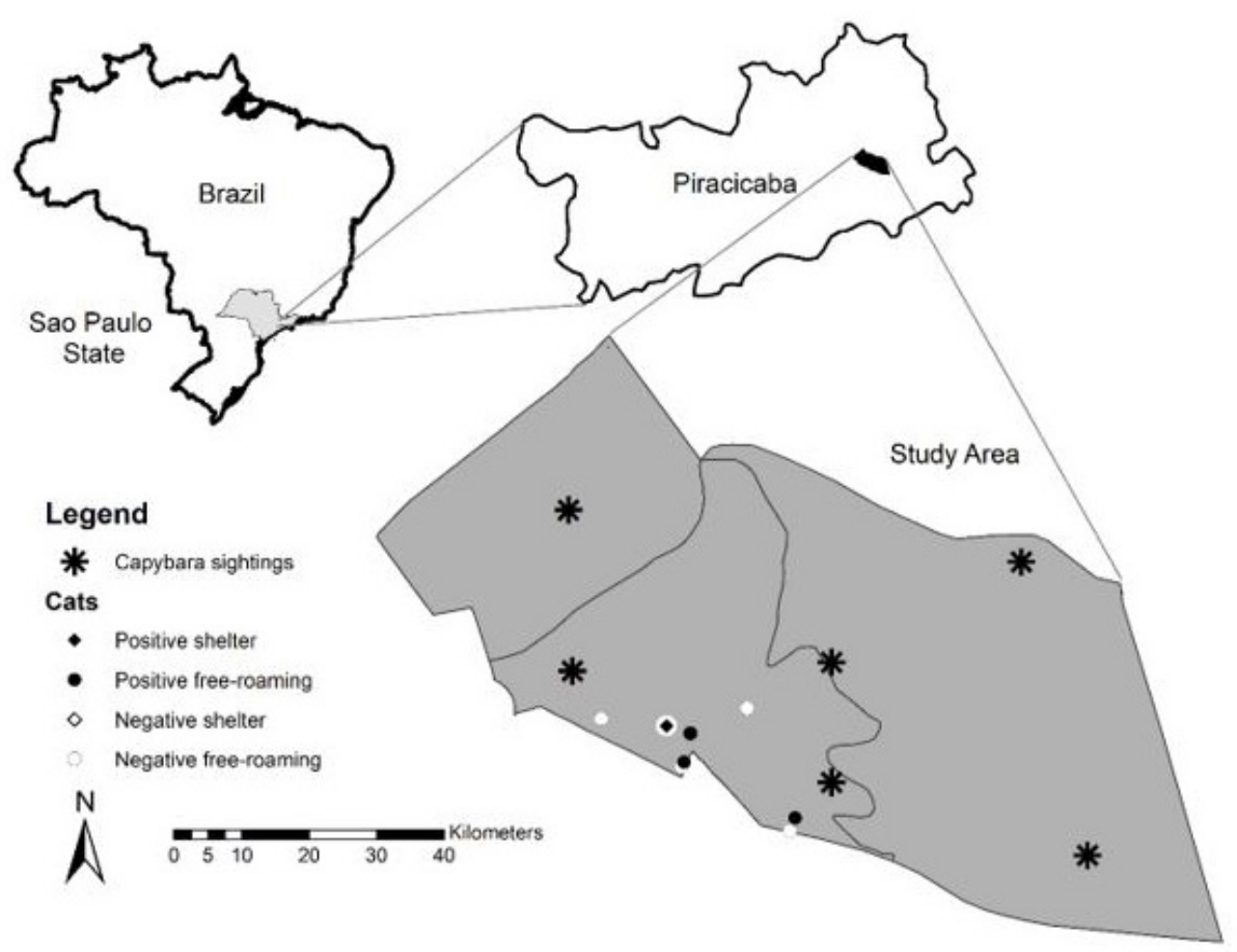

Figure 1. Spatial location of capybara sightings and locations of shelter and free-roaming cats, sampled at the "Luiz de Queiroz" School of Agriculture (ESALQ), University of São Paulo (USP), in the city of Piracicaba, between July and October 2017.

\section{Tick collection and testing}

After blood samples had been taken, the cats were carefully examined for the presence of ticks. All the ticks obtained were collected and preserved in isopropyl alcohol until analysis at the laboratory for taxonomic identification, which was performed following standard morphological keys, as previously described (ARAGĀO \& FONSECA, 1961; BARROS-BATTESTI et al., 2006; MARTINS et al., 2010).

Amblyomma sculptum tick nymphs were individually subjected to DNA extraction using the guanidine isothiocyanate technique (SANGIONI et al., 2005) and were individually tested by means of standard polymerase chain reaction (PCR) for tick mitochondrial 16S rRNA (MANGOLD et al., 1998) and the rickettsial gene gltA (LABRUNA et al., 2004). For each PCR run, a negative control (water) and a positive control (Rickettsia vini DNA) were also included, as previously described (NOVAKOVA et al., 2016).

\section{Epidemiological data and statistical analysis}

Individual information and epidemiological data were obtained and analyzed. Statistical analysis was performed by means of the Epi Info statistical software, version 3.5.2 to determine the association between Rickettsia sp. antibodies and the variables (age, sex and sterilization). The data were evaluated by determining the odds ratios and $95 \%$ confidence intervals. A nonparametric test (Fisher's exact test) was used for univariate analysis and the significance level was determined as $\mathrm{p}<0.05$.
A map showing spatial locations of capybara sightings and locations of shelter and free-roaming cats was designed using the ArcGIS software, version 10.0 (Figure 1).

\section{Ethical approval}

The present study was approved by the Ethics Committee for Animal Use of the Setor de Ciências Agrárias da Universidade Federal do Paraná (protocol no. 103/2017).

\section{Results}

A total of $28 / 51$ cats (54.9\%) were seropositive for at least one of the three Rickettsia species tested: 23/35 (65.7\%) of the shelter cats and 5/16 (31.2\%) of the free-roaming cats.

Among the free-roaming cats, $3 / 16(18.8 \%)$ reacted to $R$. rickettsii and $5 / 16(31.2 \%)$ reacted to $R$. parkeri, and the IFA endpoint titers ranged from 64 to 1024 for $R$. rickettsii and 64 to 256 for $R$. parkeri. Among the shelter cats, 16/35 (45.7\%) reacted to $R$. rickettsii and $17 / 35$ (48.6\%) reacted to $R$. parkeri, and the IFA endpoint titers ranged from 64 to 512 for $R$. rickettsii and 64 to 1024 for $R$. parkeri. Only $3 / 51$ (5.8\%) sheltered cats were seropositive for $R$. felis with titer of 64 ; these three cats were also seropositive for $R$. rickettsii and $R$. parkeri (Table 1). No statistically significant differences were found between the groups (shelter and free-roaming) regarding the frequencies of occurrence of $R$. rickettsii (OR 0.2; 95\% CI 0.07-1.13; $\mathrm{p}=0.12$ ) and $R$. parkeri (OR 0.5; 95\% CI 0.14-1.68; $\mathrm{p}=0.36$ ). Because 
Table 1. Seropositive cats and dogs to Rickettsia spp. sampled at the University of Sáo Paulo at Piracicaba city, "Luiz de Queiroz" School of Agriculture (ESALQ-USP) from July to October 2017.

\begin{tabular}{|c|c|c|c|c|c|c|c|c|}
\hline \multirow{2}{*}{$\begin{array}{c}\text { Sample } \\
\text { identification }\end{array}$} & \multirow{2}{*}{ Habitat } & \multirow{2}{*}{$\begin{array}{c}\text { Age } \\
\text { (months) }\end{array}$} & \multirow{2}{*}{ Sex } & \multicolumn{3}{|c|}{ Titers } & \multirow{2}{*}{ PAIHR* } & \multirow{2}{*}{$\begin{array}{c}\text { Presence of } \\
\text { ticks }\end{array}$} \\
\hline & & & & R. rickettsii & R. parkeri & R. felis & & \\
\hline \multicolumn{9}{|l|}{ Cats } \\
\hline 12 & Shelter & 7 & Sterilized male & 64 & NR & 64 & & \\
\hline 14 & Shelter & 7 & Female & 128 & 512 & NR & & \\
\hline 15 & Shelter & 12 & Sterilized male & 256 & NR & NR & & \\
\hline 17 & Shelter & 7 & Sterilized female & 128 & 128 & NR & & \\
\hline 19 & Shelter & 7 & Female & 128 & NR & NR & & \\
\hline 21 & Shelter & 9 & Sterilized male & 64 & 64 & NR & & \\
\hline 22 & Shelter & 12 & Sterilized male & NR & 64 & NR & & \\
\hline 23 & Shelter & 7 & Female & 256 & 128 & NR & & \\
\hline 25 & Shelter & 7 & Sterilized male & NR & 128 & NR & & \\
\hline 26 & Shelter & 7 & Sterilized male & 64 & NR & NR & & \\
\hline 27 & Shelter & 60 & Sterilized male & 512 & 64 & NR & R. rickettsii & \\
\hline 28 & Shelter & 60 & Sterilized female & NR & 64 & NR & & \\
\hline 29 & Shelter & 7 & Sterilized female & 128 & NR & NR & & \\
\hline 31 & Shelter & 7 & Female & NR & 64 & NR & & \\
\hline 33 & Shelter & 7 & Sterilized female & 256 & 512 & 64 & & \\
\hline 34 & Shelter & 48 & Sterilized female & NR & 256 & NR & & \\
\hline 35 & Shelter & 48 & Sterilized female & NR & 512 & NR & & \\
\hline 36 & Shelter & 7 & Sterilized male & 128 & NR & NR & & \\
\hline 37 & Shelter & 48 & Sterilized female & 256 & 512 & NR & & \\
\hline 38 & Shelter & 36 & Sterilized female & 512 & 1024 & NR & & \\
\hline 39 & Shelter & 24 & Sterilized female & 128 & 64 & NR & & \\
\hline 41 & Shelter & 3 & Male & NR & 64 & NR & & \\
\hline 42 & Shelter & 3 & Male & 256 & 128 & 64 & & \\
\hline 06 & Free-roaming & 36 & Male & 128 & 256 & NR & & \\
\hline 07 & Free-roaming & - & Female & 64 & 64 & NR & & \\
\hline 08 & Free-roaming & - & Male & NR & 64 & NR & & \\
\hline 49 & Free-roaming & 36 & Male & 1024 & 64 & NR & R. rickettsii & $\begin{array}{c}4 \text { Amblyomma } \\
\text { sp., } \\
5 \text { Amblyomma } \\
\text { sculptum and } \\
1 \text { Rhipicephalus } \\
\text { sanguineus } \\
\text { sensu lato }\end{array}$ \\
\hline \multirow[t]{3}{*}{50} & Free-roaming & 8 & Sterilized male & NR & 128 & NR & & \\
\hline & \multicolumn{2}{|c|}{ Yes/ Total (\%) } & & $\begin{array}{c}19 / 28 \\
(67.8 \%)\end{array}$ & $22 / 28(78.6 \%)$ & $3 / 28(10.7 \%)$ & & \\
\hline & \multicolumn{2}{|c|}{ Yes/ Overall Total (\%) } & & & $28 / 51(54.9 \%)$ & & & $1 / 28(0.03 \%)$ \\
\hline \multicolumn{9}{|l|}{ Dogs } \\
\hline 5 & Shelter & 96 & Female & 512 & 512 & NR & & \\
\hline 6 & Shelter & 60 & Female & NR & 128 & NR & & \\
\hline 7 & Shelter & 48 & Female & 64 & 64 & NR & & \\
\hline 8 & Shelter & 24 & Male & NR & 128 & NR & & \\
\hline 10 & Shelter & 108 & Male & 1024 & 1024 & NR & & \\
\hline 13 & Shelter & 36 & Female & NR & 128 & NR & & \\
\hline \multicolumn{4}{|c|}{ Yes/ Total (\%) } & $3 / 6(50.0 \%)$ & $6 / 6(100.0 \%)$ & $0 / 6(0.0 \%)$ & & \\
\hline \multicolumn{4}{|c|}{ Yes/ Overall Total (\%) } & & $6 / 12(50.0 \%)$ & & & $0 / 12(0.0 \%)$ \\
\hline
\end{tabular}

*PAIHR: probable antigen involved in homologous reaction. 
of the low number of $R$. felis-seropositive cats, they were included in the statistical analyses.

Among the shelter dogs, 6/12 (50.0\%) were seropositive for at least one of the two Rickettsia species tested: 3/6 (50.0\%) reacted to $R$. rickettsii and 6/6 (100.0\%) reacted to $R$. parkeri. No dog serum reacted to $R$. felis. The IFA endpoint titers ranged from 64 to 1024 for $R$. rickettsii and $R$. parkeri, and 64 for $R$. felis (Table 1 ).

Four larvae of Amblyomma spp., five nymphs of Amblyomma sculptum and one adult of Rhipicephalus sanguineus sensu lato were collected from the free-roaming cats: $1 / 5(20 \%)$ of the seropositive cats had ticks and $2 / 11(18.2 \%)$ of the seronegative cats had ticks (Table 1). No ticks were found on the dogs. No statistically significant association was found between the presence of ticks and rickettsiae seropositivity (OR 1.1; 95\% CI 0.08-16.31; $\mathrm{p}=1.00$ ). Three $A$. sculptum tick nymphs collected from 3/16 (18.75\%) of the free-roaming cats were randomly selected for detection of SFG rickettsial DNA by means of PCR. No rickettsial DNA was detected in these ticks, even though amplicons targeting tick 16S rRNA gene were produced through PCR to ensure successful extraction.

The frequencies and associations between individuals, and the epidemiological data, are shown in Table 2 . There was a statistically significant association between Rickettsia seropositivity and age $(\mathrm{p}=0.04)$, but not with sex $(\mathrm{p}=1.00)$ or sterilization $(\mathrm{p}=0.77)$. The difference in seroprevalence between shelter and free-roaming cats was also statistically significant $(\mathrm{p}=0.03)$. Animals under 12 months old had a 4.3 times (95\% CI 1.22 - 15.54) higher chance of being exposed to SFG rickettsiae than animals over 12 months old. This association was independent of the environment, since age was not significant when the cats were divided between a shelter group $(\mathrm{p}=0.16)$ and a free-roaming group $(\mathrm{p}=0.45)($ Table 2$)$.

Table 2. Risk factors association among living status, age, sex and sterilization with Rickettsia seropositivity frequency of animals and groups (shelter and free-roaming), sampled at the University of São Paulo at Piracicaba city, "Luiz de Queiroz" School of Agriculture (ESALQ-USP) from July to October 2017.

\begin{tabular}{|c|c|c|c|c|}
\hline \multirow{2}{*}{ Cats } & \multicolumn{2}{|c|}{ Rickettsia frequency (\%) } & \multirow{2}{*}{ Odds Ratio } & \multirow{2}{*}{$\mathbf{p}$} \\
\hline & Positive & Total & & \\
\hline \multicolumn{5}{|l|}{ Living status } \\
\hline Free-roaming & $5(31.2)$ & $16(100.0)$ & $0.2(0.07-0.84)$ & 0.03 \\
\hline Shelter & $23(65.7)$ & $35(100.0)$ & & \\
\hline \multicolumn{5}{|l|}{ Age } \\
\hline Up to 12 months & $15(75.0)$ & $20(100.0)$ & $4.3(1.22-15.54)$ & 0.04 \\
\hline Over 12 months & $11(40.7)$ & $27(100.0)$ & & \\
\hline \multicolumn{5}{|l|}{ Sex } \\
\hline Male & $14(56.0)$ & $25(100.0)$ & $1.1(0.36-3.29)$ & 1.00 \\
\hline Female & $14(53.8)$ & $26(100.0)$ & & \\
\hline \multicolumn{5}{|l|}{ Sterilization } \\
\hline Intact & $10(50.0)$ & $20(100.0)$ & $0.72(0.23-2.24)$ & 0.77 \\
\hline Neutered & $18(58.1)$ & $31(100.0)$ & & \\
\hline \multirow{2}{*}{ Groups } & \multicolumn{2}{|c|}{ Rickettsia frequency (\%) } & \multirow{2}{*}{ Odds Ratio } & \multirow{2}{*}{$\mathbf{p}$} \\
\hline & Positive & Total & & \\
\hline \multicolumn{5}{|l|}{ Age } \\
\hline \multicolumn{5}{|l|}{ Shelter } \\
\hline Up to 12 months & $14(77.8)$ & $18(100.0)$ & $3.11(0.72-13.44)$ & 0.16 \\
\hline Over 12 months & $9(52.9)$ & $17(100.0)$ & & \\
\hline \multicolumn{5}{|l|}{ Free-roaming } \\
\hline Up to 12 months & $1(50.0)$ & $2(100.0)$ & $4.00(0.16-95.76)$ & 0.45 \\
\hline Over 12 months & $2(20.0)$ & $10(100.0)$ & & \\
\hline \multicolumn{5}{|l|}{ Sex } \\
\hline \multicolumn{5}{|l|}{ Shelter } \\
\hline Male & $10(66.7)$ & $15(100.0)$ & $1.08(0.26-4.42)$ & 1.00 \\
\hline Female & $13(65.0)$ & $20(100.0)$ & & \\
\hline \multicolumn{5}{|l|}{ Free-roaming } \\
\hline Male & $4(40.0)$ & $10(100.0)$ & $3.33(0.28-40.29)$ & 0.58 \\
\hline Female & $1(16.7)$ & $6(100.0)$ & & \\
\hline \multicolumn{5}{|l|}{ Sterilization } \\
\hline \multicolumn{5}{|l|}{ Shelter } \\
\hline Intact & $6(75.0)$ & $8(100.0)$ & $1.76(0.30-10.47)$ & 0.68 \\
\hline Neutered & $17(63.0)$ & $27(100.0)$ & & \\
\hline \multicolumn{5}{|l|}{ Free-roaming } \\
\hline Intact & $4(33.3)$ & $12(100.0)$ & $1.50(0.12-19.44)$ & 1.00 \\
\hline Neutered & $1(25.0)$ & $4(100.0)$ & & \\
\hline
\end{tabular}




\section{Discussion}

To the authors' knowledge, the present study was the first concomitant report of overlapping free-roaming cat and capybara populations in an area endemic for BSF. Although antibodies against both Rickettsia rickettsii and Rickettsia parkeri have previously been reported in cats and human cases from areas of the state of São Paulo that are endemic or nonendemic for BSF (HORTA et al., 2007), only stray or owned cats were surveyed. $R$. rickettsii is the most important tick-borne zoonotic agent, and it is primarily transmitted to humans and other vertebrates by $A$. sculptum and Amblyomma aureolatum (Pallas) (LABRUNA et al., 2011, 2017).

The seroconversion of Rickettsia bellii has been reported in capybaras of southern Brazil (FORTES et al., 2011). Nonetheless, a previous study conducted in the same area of the present study, even with several positive sera of opossums, dogs, cats, horses, and humans to $R$. bellii and $R$. felis, no antibody response has been observed to these agents, probably due to similar or low titers in comparison with titers to $R$. rickettsii or $R$. parkeri (HORTA et al., 2007). These results may be explained by the low frequency of Amblyomma dubitatum and consequently $R$. bellii in the same area (HORTA et al., 2004), and the unconfirmed vector competence of fleas for Rickettsia felis transmission (WEDINCAMP \& FOIL, 2000).

Only two cats presented any antigen that was possibly involved in a homologous reaction (PAIHR) for $R$. rickettsii. As previously described in IFA tests, $R$ rickettsii and $R$. parkeri showed considerable cross-reactivity (BEATI et al., 1994). Nonetheless, seropositivity among free-roaming cats in an area with overlapping capybara distribution may suggest that cats have a role as sentinels in relation to human exposure to SFG rickettsiae, as previously observed among owned cats (HORTA et al., 2007; MATTHEWMAN et al., 1997). In the present study, $R$. parkeri strain At24, mentioned as sensu stricto and isolated from Amblyomma triste ticks Koch in Paulicéia County, state of Sáo Paulo-Brazil, has been used as the only crude antigen of $R$. parkeri to IFA (SILVEIRA et al., 2007). Even so, a previous study has already shown that the serological response of dogs to $R$. parkeri sensu stricto (strain At24) and $R$. parkeri strain Atlantic rainforest were the same (SZABÓ et al., 2013). Thus, differentiation between $R$. parkeri sensu stricto and the rest of strains mentioned as $R$. parkeri sensu lato may not be possible using solely IFA with crude antigens. Finally, the low endpoint titers (64) to $R$. felis in three cats of the present study is likely to be a result of cross-reaction with SFG rickettsiae, as previously demonstrated for $R$. rickettsii-infected dogs (PIRANDA et al., 2008).

Stray cats trapped in forest edges from Piracicaba city were all (7/7; 100\%) found to be seropositive for $R$. rickettsii and mostly (6/7; 85.7\%) seropositive for $R$. parkeri (HORTA et al., 2007). These frequencies were higher than in the present serosurvey on both free-roaming and shelter cats (Table 3). These differences were probably due to the presence of infected capybara ticks where cats were sampled in previous study.

The IFA endpoint titers for Rickettsia spp. ranged from 64 to 1024 in both groups. Similar outcomes for both antigens have previously been reported, but a few cats have presented higher titers of 2048 for both antigens (HORTA, 2006). Contrary to previous studies that did not shown any significant association between seropositivity for rickettsiae and habitat or outdoor activities (CASE et al., 2006; SEGURA et al., 2014), the present study showed that free-roaming cats had $80 \%$ lower likelihood of exposure to Rickettsia than shelter cats. We hypothesize that an outbreak of rickettsiae prior to cat rescue or while at the shelter may have occurred and may have led to seroconversion among the shelter cats.

Cats younger than 12 months had 4.3 times higher chance of seropositivity than older cats in the present study (Table 2). Although evidence of increasing exposure to $R$. rickettsii as a function of cat age was found in a previous study (CASE et al., 2006); other studies have not found any association between age and seropositivity for rickettsiae (SOLANO-GALLEGO et al., 2006; SEGURA et al., 2014). Younger cats have been found to

Table 3. Cat worldwide seroprevalence against Rickettsia rickettsii and $R$. parkeri, according to available literature.

\begin{tabular}{|c|c|c|c|}
\hline Location & Cat population & $\begin{array}{l}\text { Rickettsia spp. and } \\
\text { seropositivity (\%) }\end{array}$ & Reference \\
\hline 28 states, USA & $\begin{array}{l}\text { Paired samples from febrile and } \\
\text { non-febrile owned cats. }\end{array}$ & $\begin{array}{l}\text { Overall } 8 / 182(4.4) \text { for } \\
\text { R. rickettsii, comprising } 6 / 91 \\
\text { (6.6) febrile and } 2 / 91(2.2) \\
\text { non-febrile cats. }\end{array}$ & (BAYLISS et al., 2009) \\
\hline California and Wisconsin, USA & Owned, shelter and feral cats. & $\begin{array}{c}29 / 170(17.05) \text { for } R \text {. rickettsii, } \\
\text { comprising } 2 / 20(10.0) \text { owned, } \\
\text { 14/114 (12.3) shelter and } 9 / 36 \\
\text { (25.0) feral cats. }\end{array}$ & (CASE et al., 2006) \\
\hline State of São Paulo, Brazil & $\begin{array}{l}\text { Cats from four endemic areas } \\
\text { (trapped stray cats). }\end{array}$ & $\begin{array}{c}\text { Overall } 16 / 19(84.2) \text { for } \\
R \text {. rickettsii and } 15 / 19(78.9) \text { for } \\
R . \text { parkeri. In city of Piracicaba, } \\
7 / 7(100 \%) \text { for } R \text {. rickettsii and } \\
6 / 7(85.7 \%) \text { for } R \text {. parkeri. } \\
\text { In addition, } 6 / 7(85.7 \%) \\
\text { were seropositive to } R \text {. felis. }\end{array}$ & (HORTA et al., 2007) \\
\hline St Kitts, West Indies & Feral cats & $22 / 52(42.3) R$. rickettsii & (KELLY et al., 2017) \\
\hline Northern California, USA & Owned cats in rural communities & 23/29 (79.3) R. rickettsii & (STEPHENSON et al., 2017) \\
\hline
\end{tabular}


be statistically more susceptible to rickettsial infection, possibly due to less efficient self-cleaning habits, particularly in relation to ixodid ticks, compared with adult cats. This greater susceptibility may lead to greater potential for outbreaks of disease in situations of infestation with infected ticks. Likewise, infestation with cat fleas (Ctenocephalides felis) is greater among younger cats than among older cats, as a direct relationship between the host's ability to groom and ectoparasite intensity (HINKLE et al., 1998). Nevertheless, a previous study in the same endemic area has shown only $R$. rickettsii and $R$. parkeri as "possible antigen involved in a homologous reaction (PAIHR)", with no cats likely infected by Rickettsia felis (HORTA et al., 2007). Moreover, cats experimentally and continuously exposed to $R$. felis-infected fleas have failed to seroconvert to $R$. felis within the first few months following infestation; actually, some cats have never seroconverted (WEDINCAMP \& FOIL, 2000). Thus, exposure to $R$. felis-infected fleas may not be a risk factor for $R$. felis seroconversion (BAYLISS et al., 2009; HORTA et al., 2010). In addition, the pathogenic role of $R$. felis has been still under debate worldwide (LABRUNA \& WALKER, 2014). Hence, it is reasonable to speculate that the young cat seropositivity could be associated with tick infestation.

Rickettsia spp. usually infect and remain inside host endothelial cells, and molecular detection has failed when blood samples are investigated (LA SCOLA \& RAOULT, 1997). Under experimental conditions of infestation with $R$. rickettsii-infected ticks, rickettsial DNA was detected through PCR in only one out of 32 blood samples $(3.1 \%)$ from rickettsemic capybaras. The rickettsemia of these PCR-negative capybaras was demonstrated by intraperintoneal inoculation of capybara blood samples into guinea pigs, which developed severe spotted fever that resulted in death or seroconversion. Thus, in the present study, no molecular investigation was made on the blood samples from these free-roaming and shelter cats.

Previous studies in the same area of Piracicaba showed that the frequencies of seropositivity for Rickettsia spp. among cats concomitantly parasitized by nymphs of Amblyomma spp. were 3/7 (42.8\%) (HORTA et al., 2007) and 6/7 (85.7\%) (PEREZ et al., 2008). Molecular testing on the ticks was not conducted in either of these previous studies, but the testing using PCR in the present study did not detect any Rickettsia spp. in A. sculptum ticks.

In the present study, $6 / 12$ shelter $\operatorname{dogs}(50.0 \%)$ were seropositive for Rickettsia spp., and among the seropositive dogs, 3/6 (50.0\%) showed titers for both $R$. rickettsii and $R$. parkeri. All of these dogs had been rescued within the campus limits but they originated from outside the campus. They were caught because of a policy of suppression of on-campus roaming of dogs.

Lastly, although feral (free-roaming) cat movement was not estimated in the present study, previous studies has been shown to undergo periodic shifts in home ranges, with mean distances of $1.2 \mathrm{~km}$ between the centers of these cats' successive home ranges (EDWARDS et al., 2001). Even with relatively low frequencies of ixodid tick infestation and cat seropositivity were found in the present study, the overlapping with capybaras' natural habitat sites may make cats potential sources for infected ticks. Whether equally or less exposed to rickettsial infection, compared with owned cats in endemic areas, free-roaming and shelter cats may be used as environmental sentinels for human exposure to SFG rickettsiae in such areas.

\section{Conclusions}

To the authors' knowledge, the present study was the first concomitant report on high free-roaming cat and capybara populations that overlapped in an area endemic for BSF. Cats under one year old may be more susceptible to ticks and rickettsial infections, probably due to kittens' less efficient tick self-cleaning habits, thus leading to the potential for disease outbreaks when associated with infestation with infected ticks. Free-roaming and shelter cats may be used as environmental sentinels for human exposure to SFG rickettsiae in such areas.

\section{Acknowledgements}

The authors are grateful to the "Luiz de Queiroz" Campus Administration Center (PUSP-LQ) for supporting the study and sample processing, and to Dr. Amanda Haisi for cat trapping and veterinary assistance. Dr. Mendes and Dr. Kmetiuk were supported by postgraduate fellowships from CNPq and CAPES, respectively.

\section{References}

Aragão H, Fonseca F. Notas de ixodologia: VIII. Lista e chave para os representantes da fauna ixodológica brasileira: notas de ixolodologia. Mem Inst Oswaldo Cruz 1961; 59(2): 115-129. http://dx.doi.org/10.1590/ S0074-02761961000200001. PMid:13861962.

Barros-Battesti DM, Arzua M, Bechara GH. Carrapatos de importância médico veterinária da Regiāo Neotropical: Um guia ilustrado para identificação de espécies. 1a ed. São Paulo: Vox/ICTTD-3/Butantan; 2006.

Bayliss DB, Morris AK, Horta MC, Labruna MB, Radecki SV, Hawley JR, et al. Prevalence of Rickettsia species antibodies and Rickettsia species DNA in the blood of cats with and without fever. J Feline Med Surg 2009; 11(4): 266-270. http://dx.doi.org/10.1016/j.jfms.2008.06.007. PMid:18786845.

Beati L, Kelly PJ, Mason PR, Raoult D. Species-specific BALB/c mouse antibodies to rickettsiae studied by western blotting. FEMS Microbiol Lett 1994; 119(3): 339-344. http://dx.doi.org/10.1111/j.1574-6968.1994. tb06910.x. PMid:8050715.

Beninati T, Genchi C, Torina A, Caracappa S, Bandi C, Lo N. Rickettsiae in Ixodid Ticks, Sicily. Emerg Infect Dis 2005; 11(3): 509-511. http:// dx.doi.org/10.3201/eid1103.040812. PMid:15789496.

Case JB, Chomel B, Nicholson W, Foley JE. Serological survey of vectorborne zoonotic pathogens in pet cats and cats from animal shelters and feral colonies. J Feline Med Surg 2006; 8(2): 111-117. http://dx.doi. org/10.1016/j.jfms.2005.10.004. PMid:16434226.

Edwards GP, De Preu N, Shakeshaft BJ, Crealy IV, Paltridge RM. Home range and movements of male feral cats (Felis catus) in a semiarid woodland environment in central Australia. Austral Ecol 2001; 26(1): 93-101. http:// dx.doi.org/10.1111/j.1442-9993.2001.01091.pp.x.

Escola Superior de Agricultura "Luiz de Queiroz" - ESALQ. Universidade de São Paulo - USP. ESALQ em números [online]. Piracicaba: USP; 2019 [cited 2019 Oct 22]. Available from: https://www.esalq.usp.br/ institucional/esalq-em-numeros

Fortes FS, Santos LC, Cubas ZS, Barros-Filho IR, Biondo AW, Silveira I, et al. Anti-Rickettsia spp. antibodies in free-ranging and captive capybaras 
from southern Brazil. Pesq Vet Bras 2011; 31(11): 1014-1018. http:// dx.doi.org/10.1590/S0100-736X2011001100013.

Gheler-Costa C, Verdade LM, Almeida AF. Mamíferos não-voadores do campus "Luiz de Queiroz", Universidade De São Paulo, Piracicaba, Brasil. Rev Bras Zool 2002; 19(Suppl. 2): 203-214. http://dx.doi.org/10.1590/ S0101-81752002000600021.

Hinkle NC, Koehler PG, Patterson RS. Host grooming efficiency for regulation of Cat Flea (Siphonaptera: Pulicidae) populations. J Med Entomol 1998; 35(3): 266-269. http://dx.doi.org/10.1093/jmedent/35.3.266. PMid:9615545.

Horta MC, Labruna MB, Pinter A, Linardi PM, Schumaker TTS. Rickettsia infection in five areas of the state of São Paulo, Brazil. Mem Inst Oswaldo Cruz 2007; 102(7): 793-801. http://dx.doi.org/10.1590/ S0074-02762007000700003. PMid:18094887.

Horta MC, Pinter A, Souza CE, Neto EJR, Souza SSAL, Soares RM, et al. Ocorrência de Rickettsia bellii em carrapatos colhidos nos Municípios de Piracicaba, Pedreira, Campinas, Itu e Cordeirópolis, Estado de São Paulo. Rev Bras Parasitol Vet 2004; 13(Suppl. 1): 364.

Horta MC, Scott FB, Correia TR, Fernandes JI, Richtzenhain LJ, Labruna MB. Rickettsia felis infection in cat fleas Ctenocephalides felis felis. Braz J Microbiol 2010; 41(3): 813-818. http://dx.doi.org/10.1590/S151783822010000300035. PMid:24031560.

Horta MC. Estudo epidemiológico de Rickettsia felis em áreas endêmicas e não-endêmicas para febre maculosa no Estado de São Paulo [tese]. São Paulo: Universidade de São Paulo, Faculdade de Medicina Veterinária e Zootecnia; 2006. http://dx.doi.org/10.11606/T.10.2006.tde-12092007-112431.

Instituto Brasileiro de Geografia e Estatística - IBGE. Piracicaba Panorama [online]. Rio de Janeiro: IBGE; 2017 [cited 2019 Oct 22] Available from: https://cidades.ibge.gov.br/brasil/sp/piracicaba/panorama

Kelly PJ, Köster L, Li J, Zhang J, Huang K, Branford GC, et al. Survey of vector-borne agents in feral cats and first report of Babesia gibsoni in cats on St Kitts, West Indies. BMC Vet Res 2017; 13(1): 331. http:// dx.doi.org/10.1186/s12917-017-1230-1. PMid:29132371.

La Scola B, Raoult D. Laboratory diagnosis of rickettsioses: current approaches to diagnosis of old and new rickettsial diseases. J Clin Microbiol 1997; 35(11): 2715-2727. PMid:9350721.

Labruna MB, Krawczak FS, Gerardi M, Binder LC, Barbieri ARM, Paz GF, et al. Isolation of Rickettsia rickettsii from the tick Amblyomma sculptum from a Brazilian Spotted Fever-endemic area in the Pampulha Lake region, southeastern Brazil. Vet Parasitol Reg Stud Rep 2017; 8: 8285. http://dx.doi.org/10.1016/j.vprsr.2017.02.007. PMid:31014644.

Labruna MB, Ogrzewalska M, Soares JF, Martins TF, Soares HS, MoraesFilho J, et al. Experimental infection of Amblyomma aureolatum ticks with Rickettsia rickettsii. Emerg Infect Dis 2011; 17(5): 829-834. http:// dx.doi.org/10.3201/eid1705.101524. PMid:21529391.

Labruna MB, Santos FC, Ogrzewalska M, Nascimento EM, Colombo S, Marcili A, et al. Genetic identification of rickettsial isolates from fatal cases of Brazilian spotted fever and comparison with Rickettsia rickettsii isolates from the American continents. J Clin Microbiol 2014; 52(10): 3788-3791. http://dx.doi.org/10.1128/JCM.01914-14. PMid:25078908.

Labruna MB, Walker DH. Rickettsia felis and changing paradigms about pathogenic Rickettsiae. Emerg Infect Dis 2014; 20(10): 1768-1769. http:// dx.doi.org/10.3201/eid2010.131797. PMid:25271441.

Labruna MB, Whitworth T, Horta MC, Bouyer DH, McBride JW, Pinter A, et al. Rickettsia species infecting Amblyomma cooperi ticks from an area in the state of Sáo Paulo, Brazil, where Brazilian Spotted Fever is endemic. J Clin Microbiol 2004; 42(1): 90-98. http://dx.doi.org/10.1128/ JCM.42.1.90-98.2004. PMid:14715737.

Labruna MB. Ecology of Rickettsia in South America. Ann NY Acad Sci 2009; 1166(1): 156-166. http://dx.doi.org/10.1111/j.17496632.2009.04516.x. PMid:19538276.

Mangold AJ, Bargues MD, Mas-Coma S. Mitochondrial 16S rDNA sequences and phylogenetic relationships of species of Rhipicephalus and other tick genera among Metastriata (Acari: Ixodidae). Parasitol Res 1998; 84(6): 478-484. http://dx.doi.org/10.1007/s004360050433. PMid:9660138.

Martins TF, Onofrio VC, Barros-Battesti DM, Labruna MB. Nymphs of the genus Amblyomma (Acari: Ixodidae) of Brasil: descriptions, redescriptions, and identification key. Ticks Tick Borne Dis 2010; 1(2): 75-99. http://dx.doi.org/10.1016/j.ttbdis.2010.03.002. PMid:21771514.

Matthewman L, Kelly P, Hayter D, Downie S, Wray K, Bryson N, et al. Domestic cats as indicators of the presence of spotted fever and typhus group Rickettsiae. Eur J Epidemiol 1997; 13(1): 109-111. http://dx.doi. org/10.1023/A:1007375718204. PMid:9062789.

Nieri-Bastos FA, Marcili A, De Sousa R, Paddock CD, Labruna MB. Phylogenetic evidence for the existence of multiple strains of Rickettsia parkeri in the new world. Appl Environ Microbiol 2018; 84(8): e02872-e17. http://dx.doi.org/10.1128/AEM.02872-17. PMid:29439989.

Novakova M, Costa FB, Krause F, Literak I, Labruna MB. Rickettsia vini n. sp. (Rickettsiaceae) infecting the tick Ixodes arboricola (Acari: ixodidae). Parasit Vectors 2016; 9(1): 469. http://dx.doi.org/10.1186/ s13071-016-1742-8. PMid:27565956.

Perez CA, Almeida AF, Almeida A, Carvalho VHB, Balestrin DC, Guimarães MS, et al. Carrapatos do gênero Amblyomma (Acari: Ixodidae) e suas relaçóes com os hospedeiros em área endêmica para febre maculosa no estado de São Paulo. Rev Bras Parasitol Vet 2008; 17(4): 210-217. http:// dx.doi.org/10.1590/S1984-29612008000400008. PMid:19265580.

Piranda EM, Faccini JL, Pinter A, Saito TB, Pacheco RC, Hagiwara $\mathrm{MK}$, et al. Experimental infection of dogs with a Brazilian strain of Rickettsia rickettsii: clinical and laboratory findings. Mem Inst Oswaldo Cruz 2008; 103(7): 696-701. http://dx.doi.org/10.1590/S007402762008000700012 . PMid:19057821.

Polo G, Labruna MB, Ferreira F. Satellite hyperspectral imagery to support tick-borne infectious diseases surveillance. PLoS One 2015; 10(11): e0143736. http://dx.doi.org/10.1371/journal.pone.0143736. PMid:26599337.

Sangioni LA, Horta MC, Vianna MCB, Gennari SM, Soares RM, Galvão MAM, et al. Ricketsial infection in animals and Brazilian Spotted Fever endemicity. Emerg Infect Dis 2005; 11(2): 265-269. http://dx.doi. org/10.3201/eid1102.040656. PMid:15752445.

São Paulo. Secretaria de Estado da Saúde. Casos autóctones confirmados de febre maculosa brasileira no estado de São Paulo de 2007 a 2019* por município de LPI e evolução. [online]. 2019. [cited june 2019] Available from: http://www.saude.sp.gov.br/resources/sucen/homepage/destaques/ nova-pasta-de-midia/casos_fmb_2007-2018_2.pdf

Segura F, Pons I, Miret J, Pla J, Ortuño A, Nogueras MM. The role of cats in the eco-epidemiology of spotted fever group diseases. Parasit Vectors 2014; 7(353): 1-13. http://dx.doi.org/10.1186/1756-3305-7353. PMid:25084969.

Solano-Gallego L, Hegarty B, Espada Y, Llull J, Breitschwerdt E. Serological and molecular evidence of exposure to arthropod-borne organisms in cats 
from northeastern Spain. Vet Microbiol 2006; 118(3-4): 274-277. http:// dx.doi.org/10.1016/j.vetmic.2006.07.010. PMid:16919405.

Silveira I, Pacheco RC, Szabó MPJ, Ramos HGC, Labruna MB. Rickettsia parkeri in Brazil. Emerg Infect Dis 2007; 13(7): 1111-1113. http://dx.doi. org/10.3201/eid1307.061397. PMid:18214195.

Souza CE, Moraes-Filho J, Ogrzewalska M, Uchoa FC, Horta MC, Souza SS, et al. Experimental infection of capybaras Hydrochoerus hydrochaeris by Rickettsia rickettsii and evaluation of the transmission of the infection to ticks Amblyomma cajennense. Vet Parasitol 2009; 161(1-2): 116-121. http://dx.doi.org/10.1016/j.vetpar.2008.12.010. PMid:19147293.

Stephenson N, Blaney A, Clifford D, Gabriel M, Wengert G, Foley P, et al. Diversity of rickettsiae in a rural community in northern California. Ticks Tick Borne Dis 2017; 8(4): 526-531. http://dx.doi.org/10.1016/j. ttbdis.2017.02.014. PMid:28274808.
Szabó MP, Nieri-Bastos FA, Spolidorio MG, Martins TF, Barbieri AM, Labruna MB. In vitro isolation from Amblyomma ovale (Acari: Ixodidae) and ecological aspects of the Atlantic rainforest Rickettsia, the causative agent of a novel spotted fever rickettsiosis in Brazil. Parasitology 2013; 140(6): 719-728. http://dx.doi.org/10.1017/S0031182012002065. PMid:23363571.

Wedincamp JJ Jr, Foil LD. Infection and seroconversion of cats exposed to cat fleas (Ctenocephalides felis Bouché) infected with Rickettsia felis. J Vector Ecol 2000; 25(1): 123-126. PMid:10925806.

Zavala-Velazquez JE, Yu XJ, Walker DH. Unrecognized spotted fever group rickettsiosis masquerading as dengue fever in Mexico. Am J Trop Med Hyg 1996; 55(2): 157-159. http://dx.doi.org/10.4269/ajtmh.1996.55.157. PMid:8780453. 